\title{
Literature Review on Primary Organizational Recruitment Sources
}

\author{
Varun Shenoy \& P. S. Aithal \\ ${ }^{1,2}$ Srinivas Institute of Management Studies, Srinivas University, Mangalore - 575 001, INDIA \\ E-mail: varun_shenoy@rediffmail.com
}

Type of the Paper: Review Paper.

Type of Review: Peer Reviewed.

Indexed in: OpenAIRE.

DOI: http://doi.org/10.5281/zenodo.1210777.

Google Scholar Citation: IJMTS

\section{How to Cite this Paper:}

Shenoy Varun \& Aithal, P. S. (2018). Literature Review on Primary Organizational Recruitment Sources. International Journal of Management, Technology, and Social Sciences (IJMTS), 3(1), 37-58. DOI: http://doi.org/10.5281/zenodo.1210777.

International Journal of Management, Technology, and Social Sciences (IJMTS)

A Refereed International Journal of Srinivas University, India.

(C) With Authors.

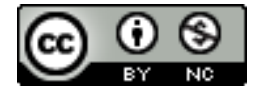

This work is licensed under a Creative Commons Attribution-Non Commercial 4.0 International License subject to proper citation to the publication source of the work.

Disclaimer: The scholarly papers as reviewed and published by the Srinivas Publications (S.P.), India are the views and opinions of their respective authors and are not the views or opinions of the SP. The SP disclaims of any harm or loss caused due to the published content to any party. 


\title{
Literature Review on Primary Organizational Recruitment Sources
}

\author{
Varun Shenoy \& P. S. Aithal \\ ${ }^{1,2}$ Srinivas Institute of Management Studies, Srinivas University, Mangalore - 575 001, INDIA \\ E-mail: varun_shenoy@rediffmail.com
}

\begin{abstract}
The process of recruitment is a primary method of people absorption function in any organization. Various companies small and big, strategize and adopt various tactics in choosing the right source of recruitment or hiring quality professionals on to their workforce. Therefore, this research aims to investigate or enquire the various research literature published on various main recruitment methods implemented in company's recruitment process or function. In this paper, the resultant outcomes based on last 20 years literature investigation are discussed in detail through a systematic review. Accordingly, the relevant resultant outcomes post the literature investigation is published by making suggestions for sustenance in the industry.
\end{abstract}

Keywords: Organizational Recruitment, Recruitment Literature Review, Company Recruitment, Strategic Recruitment Analysis, Hiring Literature Survey.

\section{INTRODUCTION :}

Recruitment being a primary Human Resource Management (HRM) function in an organization has a high significance. Recruitment process in an organization is normally carried out in corporate as well as in business level. In Corporate level, Recruitment is a part of Organization's overall Human Resource Management (HRM) Strategies that are formulated through discussions and instructions of the board. Recruitment at a corporate level normally takes place through high level references and executive manpower consultancy firms or professional associations. In Business Level, the actual practice is carried out through execution of the tasks through following the entire life cycle of the recruitment process. It is at the business level where the executives attract and source the requirements from the field or market to cater either to the business or corporate by the implementation of proper training methodologies [1-2]. Talent attraction in the dynamic changing business environment has always puzzled the HR and Functional Management. Direct Interviews with HR has always revealed recruitment always been about relationship building. Attraction implies initiatives soliciting candidate inquiries. This is primarily being carried out through advertising vacancies with the expectation that they will attract candidates meeting the essential parameters. This technique tends to be quite passive, as the employer relies on the advertisement to do most of the groundwork. An increasingly popular attraction tool is the utilization of effective employer branding strategies. This generally in the present age involves creating an employer branded web page designed specifically to create a talent database of candidates registering into an online talent database. While this is a great methodology to present a recruiter's brand as an employer, it still depends on candidates taking action, or having a motivation to investigate career opportunities at the organization. Sourcing, on the other hand, is an active effort by the recruiting organizations to find and contact candidates who have not applied for a role or registered into a talent database. These candidates are essentially being searched in the market, and may not even have an online presence. These candidates will often be highly sought after, and accordingly may not depend on lodging job applications for discovering future opportunities. In the present 
market situations, these on-demand candidates are unaware and require a certain style of contacting to lure away from their current opportunities to consider moving to another organization, let alone another industry sector. These candidates are essentials of the job market that every organization wants to consider for staffing their role or position requirements. Whatever sourcing or hiring method adopted, some active or planned, but persistent tactics are needed for this approach to yield results. It is deceptively easy to lose these candidates through a lack-lustre approach or poorly executed recruitment or hiring strategy. However, it definitely takes time, more time than expected, that's for sure for a company to choose the most ideal channel or source of recruitment. Sourcing is a methodology that many organizations are running into an under increasing pressure to outperform their competitors in the market and in some instances the only way to find the talent necessary to make

Table 1: Current Channels or Sources of Recruitment gathered through field direct interaction with HR that happen. As for this research is concerned, the problem statement : can my organization actively attract talent that will drive the company or business beyond the competition in the market? Well, to answer this research question, this paper will review the various publications on different methods of recruitment carried out through various sourcing channels by the organizations.

\section{IDENTIFIED ORGANIZATIONAL RECRUITMENT SOURCES OR CHANNELS ADOPTED IN THE INDUSTRY :}

However to source manpower, through series of field direct interview conducted with the HR industry fraternity, currently following types of recruitment methodologies are identified by the organizations in the business level whose strategies are usually formulated at corporate level depicted in the table 1.

\begin{tabular}{|c|c|}
\hline \multicolumn{2}{|c|}{$\begin{array}{c}\text { Channels or Sources of Recruitment gathered through field direct interaction with HR used by } \\
\text { business organizations }\end{array}$} \\
\hline (a) Direct Physical Campus Recruitment & (b) Direct Online or E- Campus Recruitment \\
\hline $\begin{array}{c}\text { (c) Recruitment through Executive Consultancies, } \\
\text { Professional Associations }\end{array}$ & $\begin{array}{l}\text { (d) Recruitment through employment search } \\
\text { websites and news media }\end{array}$ \\
\hline $\begin{array}{l}\text { (e) Online Recruitment, Online or E-Hiring or E- } \\
\text { Recruitment }\end{array}$ & $\begin{array}{l}\text { (f) Candidate Direct Application in response to } \\
\text { job advertisements or job portals or } \\
\text { organizational websites }\end{array}$ \\
\hline $\begin{array}{l}\text { (g) Internal Job Posting (IJP), Employee Referral, } \\
\text { Network Hiring and Rehiring, Internships and } \\
\text { Apprenticeships }\end{array}$ & $\begin{array}{l}\text { (h) Candidate Direct Walk-in in response to job } \\
\text { fairs or advertisements }\end{array}$ \\
\hline $\begin{array}{l}\text { 3. OBJECTIVES OF THE LITERATURE } \\
\text { STUDY : }\end{array}$ & $\begin{array}{l}\text { and how does organization employ the technique } \\
\text { to select and place its human resources in } \\
\text { alignment with the business goals. The research }\end{array}$ \\
\hline $\begin{array}{l}\text { This study is primarily taken up to determine the } \\
\text { various types of hiring or recruitment methods } \\
\text { prevailing in the market. The aim is also to } \\
\text { compare the literature published or researched } \\
\text { with prevailing industry practices. Efforts are } \\
\text { also undertaken to ascertain the different } \\
\text { recruitment techniques used for the organization }\end{array}$ & $\begin{array}{l}\text { also scrutinizes the various literatures } \\
\text { undertaken to know the hiring methodology } \\
\text { concept and what further research is being done } \\
\text { currently and where are the directions headed for } \\
\text { an ideal methodology for organizational } \\
\text { recruitment. The Study is also undertaken to } \\
\text { present the current industry, determine the future }\end{array}$ \\
\hline
\end{tabular}


outlook for survival in the industry as well as suggestions for focus areas in future.

\section{SCHOLARLY REVIEW OF LITERATURE FOR MAJOR ORGANIZATIONAL RECRUITMENT TECHNIQUES :}

Many research investigations are conducted pertaining to various methodologies or channels adopted towards organizational recruitment. Primarily, organizations focus on calling for candidates through direct applications by placing advertisements in their own websites, employment search websites and newspapers. Drake, L. R., Kaplan, H. R., \& Stone, R. A. (1973) in their study entitled Organizational performance as a function of recruitment criteria and effectiveness Surveyed 258 business organizations which recruit graduating students at universities and obtained 195 (75\%) responses [3]. Analysis indicated that organization size, company age, and primary activity had significant effects on responses. The recruiter screens candidates and often influences hiring decisions. It is noted that organizations had objective methods for evaluating recruiter performance, have few incentives for hiring the best candidate, and few training programs for their interviewers, yet selection criteria tend to be very subjective and nebulous. Decker, P. J., \& Cornelius, E. T. (1979) on their study entitled A note on recruiting sources and job survival rates observed several recruiting sources for obtaining new workers used by an insurance company, a bank, and a professional abstracting service were compared in terms of their relationship to later job survival [4]. Types of jobs studied included clerical, managerial, professional, and sales. Significant differences were found among the various recruiting sources in their relationship to later employee turnover. Breaugh, J. A. (1981)studied Relationships between recruiting sources and employee performance, absenteeism, and work attitudes[5].This field study sought to determine whether the sources through which employees are recruited are related to subsequent job performance, absenteeism, and work attitudes. The study found strong source-of-recruitment effects. Newspapers and college placement offices were, in general, poorer sources of employees than journal/convention advertisements and self-initiated contacts. Study results in the paper on A note on variations in recruiting information obtained through different sources by Quaglieri, P. L. (1982) show that informal sources and those tapped by "walking into" an organization for interview provided more specific and accurate information about jobs than did formal sources (i.e., newspaper advertisements, agencies, and job openings listed in professional journals) [6]. Caldwell, D. F., \& Spivey, W. A. (1983)also studied the relationship between recruiting source and employee success: An analysis by race[7]. Using a racially mixed sample $(N=1400)$ of store clerks, the relationship between recruiting source and employee success was examined. The results suggest that for Whites, informal recruiting sources (e.g., employee referrals, instore notices) were associated with longer tenure, generally confirming earlier research. For Blacks, more formal sources (e.g., employment agencies, media announcements) were associated with longer tenure. These results are discussed in terms of their implications for practice. Olian, J. D., \& Rynes, S. L. (1984) continued research in organizational staffing through their study Integrating practice with strategy [8]. This paper speaks about organizational strategies determine the ways of screening applicants. Ultimately, the organization must decide whether to hire a given candidate, continue looking, or abandon the search from the strategies adopted. As per the study, recruitment is the best marketing strategy for a company to use with job candidates is to describe job/organizational characteristics as accurately as possible. Taylor, M. S., \& Bergmann, T. J. (1987) in this regard conducted a study entitled organizational recruitment activities and applicants' reactions at different stages of the recruitment process [9]. Results in this paper show that recruitment activities were significantly related to samples reactions only at the initial interview stage. Job attributes emerged as significant predictors of samples' reactions at each of the 4 recruitment methods 
such as campus interview, during post-campus stage, company site visit or walk-ins in relation to the job offer and applicant's decision. Suggestions for strengthening organizational recruitment programs and for directing further research are discussed in this paper. Atkins, C. P., \& Kent, R. L. (1988) argued that the top $25 \%$, samples ranked overall oral communication skills as most important, followed by enthusiasm, motivation, credentials, and degree (in that order). Ranked in the bottom $25 \%$ were sense of humour, report-writing skills, summer or part-time job experience, ability to resolve conflict, and extracurricular activities [10]. The study entitled what do recruiters consider important during the employment interview? was conducted to determine recruiters' attitudes regarding hiring characteristics (communication, appearance, job selection) and their impact during the initial campus interview. 95 recruiters (from business and industry, hospital and clinics, and public education) responded to a 60 -item questionnaire. Breaugh, J. A. (2008) in his study Employee recruitment: Current knowledge and important areas for future research review research on recruitment topics that have received considerable attention (e.g., recruitment methods, realistic job previews) [11]. Author also address topics (e.g., targeted recruitment, the site visit) that have received relatively little attention but that have the potential to be quite important. In examining these topics, job applicant variables (e.g., self-insight), that should influence how an employer conducts the recruitment process but that have frequently been neglected, are discussed. Throughout the paper, important areas for future research are suggested. Carroll, M., Marchington, M., Earnshaw, J., \& Taylor, S. (1999) also covered Recruitment methods in small firms [12]. The article summarises findings from recent case study research into recruitment in small firms. The research aims to ascertain whether small firms follow the procedures outlined in the prescriptive literature on recruitment, and to what extent they rely on informal recruitment methods. It finds little evidence of the adoption of the recommended systematic procedures and a high use of "tried and trusted" methods including word-of-mouth recruitment and the hiring of "known quantities". The implications of this are examined. While these methods have certain advantages, they may also give rise to a number of problems. The study argues that the adoption of more formal procedures and methods could reduce staff turnover in small firms and its associated costs. However, it concludes that many small employers would remain unconvinced by the case for opening up recruitment channels, and may find their existing approaches more cost effective in the short term. Piotrowski, C., \& Armstrong, T. (2006) in research titled Current recruitment and selection practices :A national survey of Fortune 1000 firms reported the findings of survey data on recruitment and pre-employment selection methods in use by HR Departments of major companies in the USA [13]. The data analysed include online pre-employment tests from 151 firms. The findings indicate that majority of companies rely on traditional recruitment and personnel selection techniques over the use of online assessment instruments. Personality testing is popular in around $20 \%$ of the firms and one-fifth of respondents plan to implement online testing in the future. Furthermore, screening for honesty-integrity (28.5\%) and violence potential (22\%) was found to be somewhat popular. Mason, N. A., \& Belt, J. A. (1986) communicated the specificity of job descriptions and the specificity of applicant qualifications contained in fictitious recruitment advertisements which were manipulated to determine their effect on the probability of response [14]. The subjects were two groups of senior-level engineering students who were designated as either qualified or unqualified (based on their cumulative grade point averages) for the jobs described in the ads. Questionnaires were used to gather data on the participants' evaluation (on a 7-point scale) of each ad in terms of the likelihood of their responding to it and its relative ranking. A repeated measures analysis of variance and summation of individual ranks were used to examine the data. Results indicated that specificity of applicant qualifications had a significant negative effect 
on probability of response for unqualified individuals. Robertson, I. T., \& Smith, M. (2001) observed thatthe main elements in the design and validation of personnel selection procedures have been in place for many years [15]. The role of job analysis, contemporary models of work performance and criteria are reviewed critically. After identifying some important issues and reviewing research work on attracting applicants, including applicant perceptions of personnel selection processes, the research on major personnel selection methods is reviewed. Recent work on cognitive ability has confirmed the good criterion-related validity, but problems of adverse impact remain. Work on personality is progressing beyond studies designed simply to explore the criterion-

Table 2: List of crucial literature determining in

\begin{tabular}{|c|c|c|c|c|}
\hline $\begin{array}{l}\text { SI. } \\
\text { No. }\end{array}$ & $\begin{array}{c}\text { Author and } \\
\text { Publication Year }\end{array}$ & & and Journal & $\begin{array}{l}\text { Volume and } \\
\text { Page Referred }\end{array}$ \\
\hline I & $\begin{array}{l}\text { rake, L. R., Kaplan, H. } \\
\text { R., \& Stone, R. A. } \\
\text { (1973) }\end{array}$ & $\begin{array}{l}\text { Organizati } \\
\text { recruitment }\end{array}$ & $\begin{array}{l}\text { formance as a function of } \\
\text { nd effectiveness. Personnel } \\
\text { ournal. }\end{array}$ & $\begin{array}{l}\text { 52(10), 885- } \\
891 .\end{array}$ \\
\hline II & $\begin{array}{l}\text { Decker, P. J., \& } \\
\text { ornelius, E. T. (1979) }\end{array}$ & $\begin{array}{r}\text { A note on re } \\
\qquad o\end{array}$ & $\begin{array}{l}\text { d job survival rates. } \\
\text { sychology }\end{array}$ & \\
\hline III & & performa & & 24( \\
\hline IV & kuagn & $\begin{array}{r}\text { A note on variat } \\
\text { from different s } \\
\text { Or }\end{array}$ & $\begin{array}{l}\text { ruiting information obtained } \\
\text { ournal of Occupational and } \\
\text { nal Psychology }\end{array}$ & \\
\hline $\mathrm{V}$ & $\begin{array}{l}\text { Caldwell, D. F., \& } \\
\text { Spivey, W. A. (1983) }\end{array}$ & $\begin{array}{l}\text { The relation } \\
\text { employee succ }\end{array}$ & $\begin{array}{l}\text { ween recruiting source and } \\
\text { analysis by race. Personnel } \\
\text { ychology }\end{array}$ & $36(1), 67-72$. \\
\hline \multicolumn{3}{|c|}{$\begin{array}{l}\text { Direct traditional campus and graduate } \\
\text { recruitment channel is also a widely practiced } \\
\text { methodology by organizations for manpower } \\
\text { selection. A study undertaken by Taylor, M. } \\
\text { S., \& Sniezek, J. A. (1984) entitled The } \\
\text { college recruitment interview: Topical content } \\
\text { and applicant reactions ; investigated the } \\
\text { content of the interview itself, the effects of } \\
\text { interview contents on applicants' reactions as } \\
\text { well as concerning organizations' use of the } \\
\text { campus interview for applicant evaluation and } \\
\text { recruitment [16]. 58 recruiters interviewing } \\
\text { through placement offices for } 4 \text { types of } \\
\text { positions (accounting, sales, general }\end{array}$} & \multicolumn{2}{|c|}{$\begin{array}{l}\text { management, and finance) returned } \\
\text { demographic questionnaires. Demographic } \\
\text { questionnaires were returned by 148 } \\
\text { applicants. Results indicate that (a) recruiters } \\
\text { showed little agreement on which topics } \\
\text { should be covered in the interview; (b) } \\
\text { individual recruiters failed consistently to } \\
\text { cover topics they believed were important; (c) } \\
\text { applicants reported the most frequently } \\
\text { mentioned content dealt with non-academic } \\
\text { issues of university life and extracurricular } \\
\text { activities; (d) applicants reacted more } \\
\text { favourably to interview content concerning } \\
\text { general job qualifications. Implications for }\end{array}$} \\
\hline
\end{tabular}

related validity of personality. Interview and assessment centre research is reviewed, and recent studies indicating the key constructs measured by both are discussed. In both cases, one of the key constructs measured seems to be generally cognitive ability. Bio-data validity and the processes used to develop bio-data instruments are also critically reviewed. The article concludes with a critical evaluation of the processes for obtaining validity evidence (primarily from meta-analyses) and the limitations of the current state of the art. Speculative future prospects are briefly reviewed. However, we have listed out five relevant researches that determined the industry practice of candidate's applicant solicitation: dustry practice of direct candidate application 
recruitment interview effectiveness are discussed. Rynes, S. L., \& Boudreau, J. W. (1986) further researched extensively on College recruiting in large organizations [17]. Directors of college recruiting for Fortune 1000 corporations were surveyed regarding a broad set of college recruiting practices and college recruiting effectiveness measures. Descriptive results suggested that most college recruiting programs diverge from normative prescriptions (e.g., little recruiter training, limited data collection, and almost no empirical evaluation of recruiting outcomes). Stepwise regression revealed several statistically significant relationships between organizational characteristics, recruiting practices, and perceived recruiting effectiveness. Some of these findings were consistent with conventional wisdom (e.g., positive relationships between perceived effectiveness and recruiter information, recruiter selection criteria, and recorded information about new hires) while others were not (e.g., negative associations between perceived effectiveness, personalization of rejection notices, training recruiters in a broad range of content areas, and the existence of a human resource information system). Turban, D. B., \& Dougherty, T. W. (1992) in their study Influences of campus recruiting on applicant attraction to firms examined the influence of recruiters behaviours and characteristics as well as interview focus and structure to applicants' attraction to the firm [18]. This study measured the attraction to firms as the expectancy and perceptions. Results indicated applicants' perception on recruiter behaviour such as interest shown on job interested candidates spoke about the highest influence of attraction. Study also reported interview focus was related to perceptions of the attractiveness of a Job. Cabellero, C. L., \& Walker, A. (2010) on their study entitled work readiness in graduate recruitment and selection: A review of current assessment methods proposed that graduate recruitment and selection differs from graduate applicants owing to generally lack of job-related experience [19]. The Research highlighted that employers are placing increasing value on graduates being work ready. Work readiness is believed to be indicative of graduate potential in terms of long term job performance and career advancement. A review of the literature has found that current graduate recruitment and selection practices lack the rigour and construct validity to effectively assess work readiness. In addition, the variety of interchangeable terms and definitions articulated by employers and academics on what constitutes work readiness suggests the need to further refine this construct. This paper argued that work readiness is an important selection criterion, and should be examined systematically in the graduate assessment process, as a construct in itself. The ineffectiveness of current assessment methods in being able to measure work readiness supports the need to develop a specific measure of work readiness that will allow more effective decision practices and potentially predict long term job capacity and performance. Malaney, G. D. (1985) in his study entitled an organizational perspective of graduate student recruitment: A resource dependence approach discussed a recent shift in the nation's demographic environment has been partially responsible for lower enrolment in higher education [20]. This has stimulated an interest in student recruitment at both the undergraduate and graduate levels. This article represents the first effort to analyse recruitment from an organizational perspective. Using a resource dependence theory, the discussion focuses on recruitment as a response of graduate education to fluctuations in the environment. However, we have listed out five relevant type of researches that reflected the industry practice of application solicitation from Graduate and Campus Students in table 3. 
Table 3 : List of prime publications ascertaining the industry practice of application solicitation from Graduate and Campus Students

\begin{tabular}{|c|c|c|c|c|}
\hline $\begin{array}{l}\text { SI. } \\
\text { No }\end{array}$ & $\begin{array}{c}\text { Author and } \\
\text { Publication Year }\end{array}$ & \multicolumn{2}{|c|}{ Title and Journal } & $\begin{array}{l}\text { Volume and } \\
\text { Page Referred }\end{array}$ \\
\hline I & $\begin{array}{c}\text { Taylor, M. S., \& } \\
\text { Sniezek, J. A. (1984) }\end{array}$ & \multicolumn{2}{|c|}{$\begin{array}{l}\text { The college recruitment interview: Topical content and } \\
\text { applicant reactions. Journal of Occupational Psychology }\end{array}$} & 57(2), 157-168 \\
\hline II & $\begin{array}{l}\text { Rynes, S. L., \& } \\
\text { Boudreau, J. W. } \\
\quad \text { (1986) }\end{array}$ & \multicolumn{2}{|c|}{$\begin{array}{c}\text { College recruiting in large organizations: Practice, } \\
\text { evaluation, and research implications. Personnel } \\
\text { Psychology }\end{array}$} & 39(4), 729-757 \\
\hline III & $\begin{array}{l}\text { Turban, D. B., \& } \\
\text { Dougherty, T. W. } \\
\text { (1992) }\end{array}$ & \multicolumn{2}{|c|}{$\begin{array}{l}\text { Influences of campus recruiting on applicant attraction to } \\
\text { firms. Academy of Management Journal }\end{array}$} & 35(4), 739-765 \\
\hline IV & $\begin{array}{l}\text { Cabellero, C. L., \& } \\
\text { Walker, A. (2010) }\end{array}$ & \multicolumn{2}{|c|}{$\begin{array}{l}\text { Work readiness in graduate recruitment and selection: A } \\
\text { review of current assessment methods. Journal of teaching } \\
\text { and learning for graduate employability }\end{array}$} & $1(1), 13-25$ \\
\hline V & $\begin{array}{l}\text { Malaney, G. D. } \\
(1985)\end{array}$ & \multicolumn{2}{|c|}{$\begin{array}{l}\text { An organizational perspective of graduate student } \\
\text { recruitment: A resource dependence approach. The Review } \\
\text { of Higher Education, }\end{array}$} & 8(4), 375-386. \\
\hline 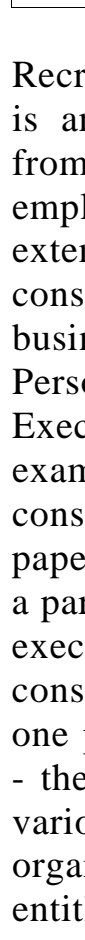 & $\begin{array}{l}\text { uitment through exec } \\
\text { nother popular metho } \\
\text { where HR so } \\
\text { loyees. Clark, I., \& } \\
\text { nsively researched or } \\
\text { ultancies for headhur } \\
\text { ness [21]. In the } \\
\text { onnel Management } \\
\text { utive Recruitment } \\
\text { nined the use of ex } \\
\text { ultants by personnel } \\
\text { r, the reasons for the } \\
\text { tticular type of consult } \\
\text { utive recruitment } \\
\text { idered. Although it } \\
\text { particular activity - ex } \\
\text { analysis has implica } \\
\text { bus recruitment n } \\
\text { nizations. Clark, T. (1 } \\
\text { led Management sele }\end{array}$ & $\begin{array}{l}\text { utive consultancies } \\
\text { dology or channel } \\
\text { arces prospective } \\
\text { Clark, T. (1990) } \\
\text { use of executive } \\
\text { ting personnel for } \\
\text { r study entitled } \\
\text { and the Use of } \\
\text { Consultancies, } \\
\text { cutive recruitment } \\
\text { managers. In this } \\
\text { rowth in the use of } \\
\text { ant by personnel or } \\
\text { consultancies are } \\
\text { is concerned with } \\
\text { ecutive recruitment } \\
\text { ions for the use of } \\
\text { lethodologies by } \\
\text { 92) in his research } \\
\text { ction by executive }\end{array}$ & \multicolumn{2}{|c|}{$\begin{array}{l}\text { recruitment consultancies: A survey and } \\
\text { explanation of selection methods further } \\
\text { presented results from two major surveys on } \\
\text { the use of selection methods by executive } \\
\text { consultancies [22]. In course of the study, it is } \\
\text { established recruitment consultancies use low } \\
\text { validity techniques using primarily } \\
\text { unstructured interviews and references. Low } \\
\text { validity selection methods are adopted } \\
\text { because validity is not the primary } \\
\text { "evaluative standard". The author finally } \\
\text { suggests five alternatives "evaluative } \\
\text { standards". Clark, T. (1993) further } \\
\text { researched on selection methods used by } \\
\text { executive search consultancies in four } \\
\text { European countries adopting a survey [23]. } \\
\text { This article identified two deficiencies in the } \\
\text { existing literature on selection methods used } \\
\text { for the recruitment of managers: 1. The } \\
\text { central focus has been the relationship } \\
\text { between the employing organization and the }\end{array}$} \\
\hline
\end{tabular}


applicant/candidate. It has been assumed that all managerial employees are recruited directly by the employing organization. As a consequence, only the selection methods used by the employer have been examined. 2. Few researchers have considered a managerial selection from a cross-national perspective, particularly in relation to the use of external recruitment consultancies. These two issues are the central concern of this article. The use of external executive recruitment consultancies is examined in four European countries: France, Germany, Italy and the UK. Results are presented from two studies on the use of selection methods by such consultancies. A significant difference between France and the UK, and these two countries and the other two, in their use of references and graphology is reported. The evidence shows that in general, German, Italian and UK search consultancies use low validity techniques, primarily unstructured interviews and references, while France makes use of these two methods in addition to graphology. It is suggested they use low validity selection methods because validity is not the primary evaluative standard by which the usefulness of selection methods is assessed. Five alternative evaluative standards are suggested: client expectations, role of consultants, consultant qualifications, impact on candidates and importance of characteristics being assessed. The utilization of different selection methods by search consultancies located in the four countries is negligible. This may be due to three factors: organizational (the form of international search network adopted), individual (the multi-cultural background experiences of consultants) and external (the nature of clients served). Christine Britton, L., \& Ball, D. F. (1994)also researched Executive search and selection consultancies in France[24].The study examined the characteristics and structure of executive recruitment consultancies in France. Search consultants recruit through "head-hunting" while selection consultants recruit through advertising. These consultancies play an important part in the market for executive recruitment. The nature of the product has implications for the behaviour of the consultancies and the structure of the industry. There is little or no price competition in the market; instead, there is a reliance on non-traditional non-price competition. There are two factors which have affected the industry: the recession, which has led to changes in the focus and role of the consultancies; and the creation of the Single European Market, which has led to the increasing internationalization of business. However, we have listed out relevant researches that reflected the industry practice of application solicitation from Executive Consultancies and Professional Associations :

Table 4: Relevant publications determining the use of Executive Consultancies and Professional Associations at Industry for recruitment

\begin{tabular}{|c|c|c|c|} 
SI. & $\begin{array}{c}\text { Author and } \\
\text { Publication Year }\end{array}$ & Title and Journal & $\begin{array}{c}\text { Volume and } \\
\text { Page Referred }\end{array}$ \\
\hline I & $\begin{array}{c}\text { Clark, I., \& Clark, T. } \\
\text { (1990) }\end{array}$ & $\begin{array}{c}\text { Personnel Management And The Use of Executive } \\
\text { Recruitment Consultancies1. Human Resource } \\
\text { Management Journal }\end{array}$ & $1(1), 46-62$. \\
\hline II & Clark, T. (1992). & $\begin{array}{c}\text { Management selection by executive recruitment } \\
\text { consultancies: A survey and explanation of selection } \\
\text { methods. Journal of Managerial Psychology }\end{array}$ & $7(6), 3-10$. \\
\hline
\end{tabular}




\begin{tabular}{|c|c|c|c|} 
III & Clark, T. (1993) & $\begin{array}{c}\text { Selection methods used by executive search consultancies } \\
\text { in four European countries: A survey and critique. } \\
\text { International Journal of Selection and Assessment }\end{array}$ & $1(1), 41-49$. \\
\hline IV & $\begin{array}{l}\text { Christine Britton, L., } \\
\text { \& Ball, D. F. (1994) }\end{array}$ & $\begin{array}{c}\text { Executive search and selection consultancies in France. } \\
\text { European business review }\end{array}$ & $94(1), 24-29$. \\
\hline
\end{tabular}

Online Recruitment or E-Recruitment is the hottest trend apparently in the Industry for sourcing Manpower. The availability and adoption of technology has become easier for HR Departments to execute the processes effectively and efficiently with proper system generated reports. The concept is also introduced to campus and graduate recruitment in the name of On-line or ECampus Placement. However, Bartram D. (2000) discussed Internet recruitment and selection through presenting the current development of the Internet as a medium in general and as recruitment and selection medium in particular [25]. This enabled the widespread adoption of computer-based assessment and predicted that it will replace paper as the default medium before very long. The research also raised a range of issues and discussions involving system security, confidentiality, authentication, control of assessment conditions, control over practice and equality of access. Piturro, M., (2000) discussed e-cruiting describing the digital process, capturing qualified candidates, including active job seekers and the passively active, and help build long-term relationships among job seekers, recruiters and hiring managers [26]. In some cases, e-cruiting makes a company's Web site a branded tool that must be marketed like any other site in need of traffic. For the candidates, it means that their resumes are always in play, even if they are unaware that such is the case or are not looking for a job. If they decide to accept overtures, they can elect when to decloak and step forward for further contact. Anderson N. (2003) presented a narrative review of applicant and recruiter reactions to new technology in employee selection [27].
Different aspects of the use of new technology are noted including computerbased testing, Internet-based recruitment and candidate assessment, telephone-based and video-based interviews, video-based situational judgment tests, and virtual reality scenarios. It is argued that an appropriate way to conceptualize these advances is as 'technical innovations' as defined in the creativity and innovation research in Industrial, Work, and Organizational (IWO) psychology. Applicant reactions research is reviewed thematically, and studies into three main themes are discussed: Applicant preferences and reactions, equivalence, and adverse impact. Bauer, T. N., Truxillo, D. M., Paronto, M. E., Weekley, J. A. and Campion, M. A. (2004) contributed to the understanding of reactions to different selection screening methods [28]. In this study, sample of students $(n=153)$ experienced one of three types of screening techniques, face-to-face interview screenings, telephone interview screenings, and interactive voice response (IVR) screenings, with identical content in a pre- to post-screening longitudinal study. Study further examined the role of two important individual differences, cognitive ability and conscientiousness, in attitudes toward the screenings. IVR is a "noninterpersonal" screening method so it was not surprising that it was rated lower in terms of procedural justice factors such as interpersonal treatment, two-way communication, and openness but what is encouraging is that there were no differences between other labour intensive and costly technologies and IVR on the other procedural justice factors. Therefore, in the paper, there do not appear to be any major negatives in 
terms of structural fairness among alternative screening devices implying that organizations can make choices between screening methods based on other factors such as recruitment strategy or cost. Ruël, H., Bondarouk, T., \& Looise, J. K. (2004) ascertained the gaps between e-HRM in a technical sense and eHRM in a practical sense in the five companies involved in their study [29]. The study reports E-HRM hardly helped to improve employee competences considering lack of human intervention, but resulted in cost reduction and a reduction of the administrative burden for business. The study also states that E-HRM is an innovation which also needs partnership from IT Departments with HRM functions; will become irritation if failure of better coordination arises between the two parties. Also, guaranteeing the security and confidentiality of input data is an important issue for stakeholders in E-HRM in order that they should feel 'safe' when using web-based HR tools. Puck, J. F., Mohr, A. T., \& Holtbrügge, D. (2006) empirically analyzed the influence of national culture on the comprehensiveness to which companies in different countries made use of corporate web site recruiting [30]. Based on Hofstede's 4Dimensions model of culture, four hypotheses are developed and tested against data from 420 companies in 14 countries. The results indicate that cultural effects are relevant even though a management technique is provided on the World Wide Web. Particularly, individualism has a strong influence on the use of corporate web site recruiting in different countries. Thus, the results lend support for the divergence approach in international management research. Maurer, S. D., \& Liu, Y. (2007) propagated the practice of using corporate websites to recruit job applicants has increased steadily [31]. The paper argued that despite this trend, however, the research studies show that approximately $75 \%$ of job seekers find the sites too complicated to use successfully as suggested by [Brown, D. (2004)]. The Study noticed a trend indicating unwanted online job seekers swamping HR staff. The study also reports that more than $20 \%$ have rejected job opportunities based on poorly designed websites as also propagated by [Pastore, M. (2000), March 29]. The article also joins Internet marketing and employee recruitment research to offer six development implications for creating an effective "e-recruitment" source on a corporate website. Based on a job marketing approach to the recruitment process and consumer behavior research on persuasive communication and decision making, we present considerations important to creating an online recruiting website that effectively influences the search decisions and behaviors of a target market of desired job candidates. Allen, D. G., Mahto, R. V., \& Otondo, R. F. (2007) research project that objective characteristics, subjective considerations, and critical contact send signals to prospective applicants about the organization and available opportunities [32]. In the generating applicants phase of recruitment, critical contact may consist largely of interactions with recruitment sources (e.g., newspaper ads, job fairs, organization Web sites); however, research has yet to fully address how all 3 types of signalling mechanisms influence early job pursuit decisions in the context of organizational recruitment Web sites. Results based on data from 814 student participants searching actual organization Web sites support and extend signalling and brand equity theories by showing that job information (directly) and organization information (indirectly) are related to intentions to pursue employment when a priori perceptions of image are controlled. A priori organization image is related to pursuit intentions when subsequent information search is controlled, but organization familiarity is not, and attitudes about a recruitment source also influence attraction and partially mediate the effects of organization information. Theoretical and practical implications for recruitment are discussed. Rozelle, A. L., \& Landis, R. S. (2002) investigated the extent to which applicant use of the Internet during 
recruitment was related to post-entry attitudes [33]. Based on the extant organizational recruitment literature, a primary hypothesis was that Internet recruitment would be perceived as presenting less realistic information to applicants as compared to informal forms of recruitment. In addition, greater applicant use of Internet-based recruiting information was expected to be associated with lower satisfaction with the organization. The data did not support the hypotheses; however, study limitations that may explain the observed findings are described. Finally, suggestions for future research involving theory building and Internet recruitment are offered. Parry, E., \& Wilson, H. (2009) examined the reasons behind an organisation's decision to use online recruitment, and reports on the development of a model of the factors affecting the adoption of this recruitment method [34]. The internet is initially hailed as the future of recruitment and is expected to replace other media as the preferred recruitment method, but the adoption of online recruitment has not been as comprehensively predicted. In addition, empirical research regarding online recruitment from an organisational perspective is sparse. The paper uses in-depth interviews and a survey of human resource (HR) managers with recruitment responsibility. The factors that affect the adoption of online recruitment are explored, and related to Rogers's diffusion of innovation theory (DIT) and Ajzen's theory of planned behaviour. Factors related to the adoption of corporate web sites and commercial jobs boards are found to be different, with positive beliefs/relative advantage, subjective norms and negative beliefs emerging in the case of corporate web sites and positive beliefs/relative advantage and compatibility for jobs boards. These results provide some fit with both Ajzen's and Rogers' factors. This paper addresses an important area that is under-researched academically and provides a basis for further research into how organisations may adopt online recruitment successfully. In research conducted by Dineen, B. R., Ash, S. R., \& Noe, R. A. (2002) on applicant attraction examined the context of Web-based recruitment [35]. A Person-Organization (P-O) fit framework was adopted to examine how the provision of feedback to individuals regarding their potential P-O fit with an organization related to attraction. Objective and subjective P-O fit, agreement with fit feedback, and self-esteem also were examined in relation to attraction. Results of an experiment that manipulated fit feedback level after a self-assessment provided by a fictitious company Web site found that both feedback level and objective $\mathrm{P}-\mathrm{O}$ fit were positively related to attraction. These relationships were fully mediated by subjective P-O fit. In addition, attraction was related to the interaction of objective fit, feedback, and agreement and objective fit, feedback, and self-esteem. Implications and future Web-based recruitment research directions are discussed. Backhaus, K. B. (2004) research explored the ways in which corporations describe themselves in recruitment materials [36]. Specifically, the study examines corporate descriptions provided to job seekers by firms advertising on the Internet site, Monster.com. The study also explores elements of corporate image presented in the descriptions and the way in which firms market their employer brands. The findings demonstrate how analysis of corporate descriptions reveals interesting insights into organizational recruitment tactics. Results suggest that firms focus predominantly on firm attributes and secondarily on employee advancement. Various industries approach recruitment advertising differently, with significant differences emerging between high-tech organizations, service organizations, and consumer product firms in the emphases of their corporate descriptions. Few firms present a distinct employer brand but tend to cluster together in brand types. Hamilton, R. J., \& Bowers, B. J. (2006) advised that in 2004, 111 million adults accessed the Internet looking for health and medical information 
[37]. Based on a above trend, qualitative researchers can apply long-standing principles of recruitment and interviewing to the Internet. The purpose of this article is to examine the theoretical and methodological aspects of Internet recruitment and e-mail interviewing. The authors address issues of appropriateness, adequacy, representativeness, sample bias, data fraud, flexibility and consistency in interviewing, timing, elimination of the need for transcription, oral versus written communication, reliability and validity, and ethical concerns. They include some practical suggestions on a research design for a qualitative study employing both Internet recruitment and e-mail interviewing. Färber, F., Weitzel, T., \& Keim, T. (2003) advise many online recruitment platforms suffer from the inappropriateness of Boolean search methods for matching candidates with job requirements [38]. While such platforms have so far been a successful means for decreasing personnel advertising cost, the huge amount of electronic candidate profiles has not yet been exploited to optimize search quality. In this paper, using findings from an empirical survey on modern recruitment practices among Germany's top 1,000 enterprises and supported by findings from personnel selection theory, we identify a gap between the actual requirements of matching people with jobs and current e-recruitment procedures. Based on information systems research and drawing from selection and assessment theory, a framework for developing new matching methods is proposed. The study describes the elements of a matching method using a probabilistic automated recommendation approach and then present first quite promising results from applying the algorithm to synthetic data. Lori Foster Thompson, Phillip W. Braddy, Karl L Wuensch.,(2008) examined the influences of website design on prospective job seekers [39]. The attractiveness of the job advertisement's formatting, the usability of the website, overall evaluations of the organization's web appeal, impressions of the organization, and willingness to pursue employment with the hiring organization were listed as criteria's for measuring the web appeal of recruiting organization. The paper found although the formatting attractiveness and usability of online recruitment materials influenced participants' inclinations to pursue jobs, formatting was more important than usability. Moreover, impressions of recruiter mediated the relationship between satisfaction with the website and willingness to pursue employment with the organization. Hella, Sylva., Stefan T. Mol. (2009) attempted to study the job applicant reactions towards web-based recruitment and selection procedures [40]. Further in the research it was observed that candidates were more satisfied with the online application procedure and its features. However, it was found that features of employer website, perceived efficiency and user-friendliness, were by far the most important determinants of applicant satisfaction. Girard, Aurelie., Fallery, Bernard., (2009) introduced the reader about the ever-evolving electronic recruitment processes which has become the integral functions of HR [41]. The research speaks about how the internet platform became a foundation for evolution of electronic HR practices. Career websites, Job Boards, Recruitment Systems is the major sourcing avenues and interviewing platforms for majority of the company in industry. The paper also argues that E-Recruitment saves massive amount of precious resources like time, travel, cost and efforts. At the same time, the study also compares two versions of e-recruitment versions to locate issues which impact the concepts. Bondarouk, T. V., \& Ruel, H. J. M. (2009) presented the challenges that arised out of integration between HRM and IT, aimed at creating value for targeted employees and managers [42]. The definition suggests challenges in e-HRM contents, implementation and consequences. Measurement of value creation for diverse groups of users in automated platform is felt as the user focus has already become a core issue in IT development and implementation. 
The paper observes that for industry the eHRM web of delivery channels and perceptions of e-HRM, reflects a grown-up stage when e-HRM involves not only the implementation of e-tools but also the creation of a clear HRM vision and (re)structuring of the HR function. The digital era of recruitment also poses conceptualizing relationships between e-HRM and human capital development, continues the discussion on the strategic use and consequences of eHRM for the industry. Doherty, R. (2010) aimed to discuss the growing popularity of social networking as a recruitment tool and to outline some of the key considerations that organizations must take when embarking on social recruiting [43]. Basically, the study revolves around Design/methodology/approach which is a best practice guide based on author's firm Job partners' experience of providing e-recruitment solutions to a number of blue-chip global companies. As employers find that their workforce is aging, there will be increasing competition to attract and retain a new, younger generation of workers. Add to this the current economic climate, where there are more applicants than jobs, and identifying external talent becomes very challenging. With pressure on the HR department to do more with less, using social networking can be a cost-effective way to attract and engage with new applicants. The article outlines best practice when it comes to social recruiting, highlighting how one major global retail brand has successfully integrated social media tools into its recruitment strategy. Holm., Anna B., (2012) found that industrial erecruitment should become a universally accepted process and lead to a better candidate relationship management in portals and platforms [44]. The present study filled the research gap by investigating the effect of e-recruitment on the design of the recruitment process. The findings indicate that erecruitment transforms the traditional recruitment process into a time- and spaceindependent, collaborative hiring process. The most significant changes are recorded in the sequence and increased divisibility of main recruitment tasks and subtasks. Thielsch, M. T., Träumer, L. \& Pytlik, L. (2012) advised more and more companies currently recruit online, partly because of cost savings and competitive pressure, and partly because it is the best way to reach their target group of applicants [45]. The paper speaks about how job applicants' ratings of procedural fairness of on-line interviews are very important for the company to align their HR practices. The study found that applicants experienced online recruitment as very positive, fair and transparent. This goes on to affirm that job seeking population of today are very comfortable and convenient in online mode of placements. Therefore, a dire need to train the young job seekers for facing online interview has arisen. Rathod, N., Shah, S., \& Shirsat, K. (2013) further advised an Online Training and Placement (OTaP) System introduced will automate the activities of training and placement cell providing a chance to the student community to use all intelligence together to increase selection ratio and eases out process of creation of management information automatically [46]. OTaP focuses on the automation of the placement cell. It allows authorizing the CVs, communicating about the various job openings to the student community, managing the corporate relationship for calling them for the placements as well other activities, creating the placement metrics, monitoring the progress of the selection process and communicating with different users. OTaPs ystem provides the module like Student (Current Student/ Alumni), Administrator (TPO/ TnP Staff/ Departmental Staff), Company and Forum. This study therefore clearly concludes that such a system is devised for matching the automated recruitment process administration requisite from the industry. Hadkar, Shilpa., Baing Snehal., Harer Trupti., Wankhede Sonam., Reddy, K.T.V. (2014) described mainly two steps of electronic placement platform, the first one step is to maintain the list of all students and their related records and another 
one step is to maintaining the company details like as their vacancies, etc. and based on the company requirements, get shortlisted list of students branch wise, which is a more complex task in traditional campus recruitment [47]. Therefore, this paper stresses on the need to have automated interview and placement management are the order of the industry and they are also expecting the same from colleges who in this case becomes supplier of manpower. Kasture, Hitesh., Saraiyya, Sumit., Malviya, Abhishek., Bhagat, Preeti. (2014) brought out an Advanced Training and Placement Web Portal (ATPWP) to automate activities of TPO cell of college that provides opportunities to the students to raise selection ratio and it maintains student's information automatically [48]. Collecting and authorizing the $\mathrm{CV}$, discussion about the various job opportunities with the students, managing the corporate relationship for inviting them for the placements, provides job openings to the alumni students who are not placed, maintaining information about placed students and then communicates with different users of system. ATPWP system provides the modules like Student (Current/ Alumni student), Administrator (TPO Staff / TPO officer / Department staff), and Forum, and Company. It has the features by using which students can search for the company reviews, Placement papers etc. TPO can arrange mock test and mock interviews using this system. Manage Company Profiles \& Job Postings, Authenticate and activate the student profiles as well as company profile, Send Notifications to students, create a list of students as per company criteria for Job Request, provides the list of shortlisted students with resume to company HR, send data of shortlisted students based on company Criteria, Manage student profiles. With this finding, industry clearly desires to align their automated recruitment systems and processes with that of their recruiting colleges. Bhad, Nilesh., Kumble Pooja., Saini, Sunita., Thorat, Yogesh., (2016). proposed the usage of OP, an automated application to provide students to register, search for company and apply for jobs [49]. The application facilitates TPO and the companies to take effective actions on the web as follow on from the information they have viewed. OP system provides information on placement providers and the placements they offer so that students may assess and view their opportunities for particular company. Comparison is further facilitated in the paper wherein an automated on-line training and placement system is advantageous when compared to traditional ones involving paper work and laborious administration purposes. Again, this research work clearly implies that industry require an electronic user-friendly interface to map the campus recruited candidates pretty swiftly to their businesses and clients. Kulkarni, Anagha., Hajare, Priyanka., Khandave, Priyanka., Adhav Shital., Pimpale, Swati. (2016) proposed a system that automates the online registration of all the user, deactivation and activation the user, resources to be provided online, personalization to the user, communication between the users, online feedback [50]. The admin of the system can see the user information and will validate it. The admin also generates the student list based on the company criteria and company details are also provided to the all users. searching and sorting can be done, and reports can be generated. Alumni data can be maintained in our system. Overall, all the process of the training and placement department is done automatically. System here ensures a minimization of the human intervention. This work propounds that existence of too much manual intervention in traditional campus recruitment process is a possible error zone for the hiring process. Therefore, a software is devised for ensuring a smooth supply of talents to match hi-tech industry requirements. Katwa, Charlotte., Kashmira Sanjana., Parmar, Pooja. (2016) advised that final year placement management system is a total electronic management and informative system, which provides the up-to date information of all job seeking candidates [51]. The home page will contain various tabs 
such as TPO login, exam cell login and student login. These tabs are linked to the login pages that will further guide them to the required page. All the users have some common services like changing password, searching for details, checking the details, mailing to administrator. Software package is developed in windows platform. The programming languages used are HTML as the front end and PHP and MySQL as the back end. This paper affirms that more and higher educational institutions in India are focusing towards a development of a robust online placement platform to match the industry requirement of E-HRM processes. Brandão, C., Morais, C., Dias, S., Silva, A. R., \& Mário, R. (2017) research stated that a growing number of organizations use new technologies in Human Resource processes [52]. Online recruitment tools allow receiving job applications, a quick triage and feedback to candidates. Organizations increasingly use online hiring process not only to recruit but also to select, hence taking advantage of the functionalities of online information systems. The theory goes on to state that companies can achieve good economies of scale as well as cost effectiveness in their HR management as well as pass on the same to their manpower provider. Shenoy, Varun., \& Aithal, P S. (2017) also introduced a new e-campus interview training model known as "The Box Framework for E-Campus Interview Training” [53]. Through conceptual study and by introducing various box contents of the framework, they demonstrated that a comprehensive online interview training plan could be designed by the trainer for a robust

Table 5: List of Publications referring to use of Online or E-Recruitment processes in Lateral and Campus Hiring's :

\begin{tabular}{|c|c|c|c|} 
SI. & Author and Year & Title and Journal & $\begin{array}{c}\text { Volume } \\
\text { and Page }\end{array}$ \\
\hline I & Piturro, M., (2000) & "The Power of E-Cruiting”, Management Review & $\begin{array}{c}89(1), 33- \\
37\end{array}$ \\
\hline II & $\begin{array}{c}\text { Bauer, T. N., Truxillo, D. } \\
\text { M., Paronto, M. E., }\end{array}$ & $\begin{array}{c}\text { Applicant Reactions to Different Selection Technology: } \\
\text { Face-to-Face, Interactive Voice Response, and Computer- }\end{array}$ & $\begin{array}{c}12(1), \\
135-148 .\end{array}$ \\
\hline
\end{tabular}

Varun Shenoy et al, (2018); www.srinivaspublication.com online e-interview preparation training program for the students. Evaluation of the training model option was also proposed under the new training framework. Earlier in the year, Shenoy, Varun., \& Aithal, P S. (2016) has conducted ABCD Analysis of Online Campus Placement Model. The determinant issues were identified and affecting factors under the constructs advantages, benefits, constraints, and disadvantages were determined under common key attributes. 158 Critical Constituent Elements were identified based on this analysis framework [54]. Continuing the research in this direction, Shenoy, Varun., \& Aithal, P S. (2016) also proposed a comprehensive "Online-oriented industry placement model"[55]. This revolutionary model blended the skill aspect of placement seeking students to align with recruiter requirements through various electronic communication methodologies. In the same year, Shenoy, Varun., \& Aithal, P S. (2016) also evidenced that Green Placement Model is also realizable in Higher education campuses [56]. The newly discovered on-line campus placement process termed as 'Green Placements' thrives as a conceptual model focused on to reduce resource wastages, save water, time, space, electricity by preserving the surrounding environment clean and green whilst the placement activity is being conducted at the college. However, we have listed out five relevant researches that reflected the industry practice of online or erecruitment lateral and e-campus placements for freshers. 


\begin{tabular}{|c|c|c|c|} 
& $\begin{array}{c}\text { Weekley, J. A. and } \\
\text { Campion, M. A. (2004) }\end{array}$ & $\begin{array}{c}\text { Assisted Telephone Screening Interviews. International } \\
\text { Journal of Selection and Assessment }\end{array}$ & \\
\hline III & Holm., Anna B., (2012) & $\begin{array}{c}\text { E-recruitment: Towards an Ubiquitous Recruitment } \\
\text { Process and Candidate Relationship Management, German } \\
\text { Journal of Research in Human Resource Management }\end{array}$ & 241 -259, \\
\hline IV & $\begin{array}{c}\text { Shenoy, Varun., \& Aithal, } \\
\text { P S. (2016) }\end{array}$ & $\begin{array}{c}\text { ABCD Analysis of On-line Campus Placement Model. } \\
\text { IRA-International Journal of Management \& Social } \\
\text { Sciences }\end{array}$ & $\begin{array}{c}5(2), 227- \\
244\end{array}$ \\
\hline V & $\begin{array}{c}\text { Shenoy, Varun., \& Aithal, } \\
\text { P S. (2017) }\end{array}$ & $\begin{array}{c}\text { A New Box Framework for E-Campus Interview Training. } \\
\text { International Journal of Applied Engineeringand } \\
\text { Management Letters (IJAEML) }\end{array}$ & $\begin{array}{c}1(2), 17- \\
26\end{array}$ \\
\hline
\end{tabular}

There are other internal practices followed as well in the hiring market. They include Direct Walk-in, IJP (Internal Job Postings), Network Hiring, Referrals, and Re-hiring. Wiley, C. (1992) tested two hypotheses addressing the causes of differential recruiting sources [57]. These include at least one realistic information and the individual difference hypotheses. The realistic information hypothesis signified that recruiting sources are different in the outcomes they yield because of the varying amounts of realistic information communicated when using that source or method (Wanous 1980). On the other hand, the individual difference hypothesis explains that recruiting sources differ in the outcomes they yield because the applicants they reach and attract are different demographically (Schwab, 1982). Employee Referrals, Rehires, and other sources which included a higher degree of job information as compared to external channels. Van Latham, M., \& Leddy, P. M. (1987) empirically investigated the relationship between recruiting methods and the work attitudes of job involvement, organizational commitment, and job satisfaction [58]. Multivariate and follow-up univariate analyses showed strong recruitment source effects, with employee referrals emerging as a better source of recruitment than newspaper advertisements. Zottoli, M. A., \& Wanous, J. P. (2001) presented the effectiveness of different recruitment sources for new employees [59]. In the Study, the effectiveness was primarily assessed by examining turnover/job survival rates and job performance. As reported in most narrative reviews and all five quantitative reviews, referrals by current personnel, in-house job postings, and the rehiring of former employees are the most effective sources. Walk-ins have been slightly less effective, and the least effective sources are newspaper ads, school placement services, and employment agencies (government/ private). Marsden, P. V. (1994) conducted a survey on U.S. establishments through using a variety of methods for publicizing the availability of job opportunities to potential workers [60]. Newspaper advertisements and informal referrals from employees are used most frequently. Referrals are more often used together with other approaches than as a sole recruitment strategy; those establishments that rely exclusively on "network hiring" tend to be small, less formalized, and in the private sector. Organizations display strong proclivities to rely on the same approaches to recruitment for different types of employees, but there are occupationally related variations in recruiting techniques. Professional referrals and advertisements are more typical approaches for high-prestige occupations than for low ones, and some variations in recruitment practices are associated with occupational gender composition. However, we have listed out relevant researches that reflected the industry practice of application solicitation through Direct Walk-in, IJP (Internal Job Postings), Network Hiring, Referrals, and Rehiring : 
Table 6: Publication list of Literature determining the use of Direct Walk-in, IJP (Internal Job Postings), Network Hiring, Referrals, and Re-hiring strategies in Industry :

\begin{tabular}{|c|c|c|c|}
\hline $\begin{array}{l}\text { SI. } \\
\text { NO }\end{array}$ & Author and Year & Title and Journal & $\begin{array}{l}\text { Volume } \\
\text { and Page }\end{array}$ \\
\hline I & Wiley, C. (1992) & $\begin{array}{l}\text { Recruitment research revisited: Effective recruiting methods } \\
\text { according to employment outcomes. Journal of Applied Business } \\
\text { Research }\end{array}$ & $8(2), 74$. \\
\hline II & $\begin{array}{l}\text { Van Latham, M., \& } \\
\text { Leddy, P. M. } \\
\text { (1987) }\end{array}$ & $\begin{array}{c}\text { Source of recruitment and employee attitudes: An analysis of job } \\
\text { involvement, organizational commitment, and job satisfaction. } \\
\text { Journal of Business and Psychology }\end{array}$ & $\begin{array}{l}1(3), 230- \\
\quad 235\end{array}$ \\
\hline III & $\begin{array}{l}\text { Zottoli, M. A., \& } \\
\text { Wanous, J. P. } \\
\text { (2001) }\end{array}$ & $\begin{array}{l}\text { Recruitment source research: Current status and future } \\
\text { directions. Human Resource Management Review, }\end{array}$ & $353-382$. \\
\hline IV & $\begin{array}{l}\text { Marsden, P. V. } \\
\text { (1994) }\end{array}$ & $\begin{array}{c}\text { The hiring process: recruitment methods. American Behavioral } \\
\text { Scientist }\end{array}$ & $\begin{array}{l}\text { 37(7), } 979- \\
\quad 991\end{array}$ \\
\hline
\end{tabular}

5. OUTCOME OF THE STUDY, is the number of variables involved and the

PRESENT AND FUTURE DIRECTIONS ALONG WITH SUGGESSIONS :

Over the last couple of decades, the amount of research on recruitment literature has increased considerably. Despite this surge, recent studies of the recruitment literature often have had adazed tone. Reviewers have determined that why recruitment activities have the effects they generally do towards the related stakeholders. Study also observes that, in order for future studies to result in a better understanding of the recruitment process through relevant sources, such studies need to be structured with a deeper analysis of the complexity of the recruitment methods. That nature of their relationships. However, this Study is structured through literature search of researches undertaken in the field by referring varied online and physical journals, on-line and offline libraries, white papers, working papers conference proceedings etc. Through analysis and interpretation of literature, the understanding of above review guides us to the fact that, certain important factors depicted in table below also importantly determine or influence the choice of right channels of manpower availability for organizational recruitment process identified in the literature review :

Table 7: Table depicting factors influencing the choice of right recruitment channels or source:

Factors influencing the choice of right recruitment channels or source in Business Organizations

\begin{tabular}{|c|c|c|}
\hline $\begin{array}{c}\text { (I) Job Seeker's } \\
\text { Communication Abilities }\end{array}$ & $\begin{array}{c}\text { (II) Job seeking Candidate's Appearance, } \\
\text { Behaviour and Etiquettes in the Interview }\end{array}$ & $\begin{array}{c}\text { (III) Candidate's Personality } \\
\text { and Attitude, Enthusiasm } \\
\text { and Motivation towards the } \\
\text { job vacancy }\end{array}$ \\
\hline $\begin{array}{c}\text { (IV) Candidate's Experience } \\
\text { Credentials, Domain } \\
\text { Knowledge and Educational } \\
\text { Degree }\end{array}$ & $\begin{array}{c}\text { (V) Candidate's Sense of humour, Report- } \\
\text { writing skills, Summer or Part-time job } \\
\text { experience, ability to resolve conflict, and } \\
\text { extracurricular activities. }\end{array}$ & $\begin{array}{c}\text { (VI) Historical Research on } \\
\text { Attrition from source or } \\
\text { channels. }\end{array}$ \\
\hline
\end{tabular}




\section{Current Scenario:}

This study makes apparently a number of relevant matters that recruitment research has yet to address. However, keeping in mind above factors, as per the study, most important being organizations are currently adopting a hybrid organizational recruitment methods or channels through comparing and blending E-Recruitment with traditional methodologies which suits the industry need Sills, M. (2014) [61].

\section{Future Hypothesis:}

The Future of recruitment is however poised more towards application of Automation, Artificial Intelligence and Robotics in candidate attraction and sourcing. With E-Recruitment platforms, E-Cruiting and E-HRM becoming an essential business function along with social media recruiting, traditional recruitment process is in the verge of fully disrupted though it is currently used in alternative along with Eprocesses of manpower recruiting.

Suggestions:

From the above review, we have constructed a suggestion table below depicting areas that may be conducive for businesses to invest as a HR Practice in achieving ideal manpower supply for carrying out their operations in coming days.

Table 8: Suggestion Table recommending focus investment areas for future recruitment channels:

\begin{tabular}{|c|c|}
\hline $\begin{array}{c}\text { I. Invest in Artificial Intelligence, } \\
\text { Automation and Robotics }\end{array}$ & $\begin{array}{c}\text { II. Invest in E-Recruitment and adopt } \\
\text { online HR Process as much as possible }\end{array}$ \\
\hline $\begin{array}{c}\text { III. Integrate HRM with core business } \\
\text { functions and not as a separate } \\
\text { department }\end{array}$ & $\begin{array}{c}\text { IV. Employ Hybrid or Mixed Method } \\
\text { Recruitment process }\end{array}$ \\
\hline
\end{tabular}

\section{CONCLUSION :}

To conclude this study, a good significant number of papers were taken up for review and understand the literature on prevailing organizational recruitment channels and techniques. The survey bought about understanding of relevant critical factors that influence the choice of right channel or sources

\section{REFERENCES:}

[1] Schuler, R. S. (1992).Strategic human resources management: Linking the people with the strategic needs of the business. Organizational dynamics, 21(1), 18-32.

[2] Farndale, E., Scullion, H., \& Sparrow, P. (2010). The role of the corporate HR function in global talent management. Journal of world business, 45(2), 161-168.

[3] Drake, L. R., Kaplan, H. R., \& Stone, R. A. (1973). Organizational performance as a of organizational recruitment. The research also signified the present and future of the recruitment methodologies using various sources or channels. Scholarly suggestions were also made to direct the stakeholders to undertake informed decisions and future investments based on this study.

function of recruitment criteria and effectiveness. Personnel Journal, 52(10), 885-891.

[4] Decker, P. J., \& Cornelius, E. T. (1979). A note on recruiting sources and job survival rates. Journal of Applied Psychology, 64(4), 463.

[5] Breaugh, J. A. (1981). Relationships between recruiting sources and employee performance, absenteeism, and work attitudes. Academy of Management journal, 24(1), 142-147.

[6] Quaglieri, P. L. (1982). A note on variations 
in recruiting information obtained through different sources. Journal of Occupational and Organizational Psychology, 55(1), 5355.

[7] Caldwell, D. F., \& Spivey, W. A. (1983). The relationship between recruiting source and employee success : An analysis by race. Personnel Psychology, 36(1), 67-72.

[8] Olian, J. D., \& Rynes, S. L. (1984). Organizational staffing: Integrating practice with strategy. Industrial relations : A journal of economy and society, 23(2), 170183.

[9] Taylor, M. S., \& Bergmann, T. J. (1987). Organizational recruitment activities and applicants' reactions at different stages of the recruitment process. Personnel Psychology, 40(2), 261-285.

[10] Atkins, C. P., \& Kent, R. L. (1988). What do recruiters consider important during the employment interview?. Journal of Employment Counselling, 25(3), 98-103.

[11] Breaugh, J. A. (2008). Employee recruitment: Current knowledge and important areas for future research. Human Resource Management Review, 18(3), 103118.

[12] Carroll, M., Marchington, M., Earnshaw, J., \& Taylor, S. (1999). Recruitment in small firms: Processes, methods and problems. Employee relation, 21(3), 236-250.

[13] Piotrowski, C., \& Armstrong, T. (2006). Current recruitment and selection practices: A national survey of Fortune 1000 firms. North American Journal of Psychology, 8(3), 489-496.

[14] Mason, N. A., \& Belt, J. A. (1986). Effectiveness of specificity in recruitment advertising. Journal of Management, 12(3), 425-432.

[15] Robertson, I. T., \& Smith, M. (2001). Personnel selection. Journal of occupational and Organizational psychology, 74(4), 441472. college recruitment interview: Topical content and applicant reactions. Journal of Occupational Psychology, 57(2), 157-168.

[17] Rynes, S. L., \& Boudreau, J. W. (1986). College recruiting in large organizations: Practice, evaluation, and research implications. Personnel Psychology, 39(4), 729-757

[18] Turban, D. B., \& Dougherty, T. W. (1992). Influences of campus recruiting on applicant attraction to firms. Academy of Management Journal, 35(4), 739-765.

[19] Cabellero, C. L., \& Walker, A. (2010). Work readiness in graduate recruitment and selection: A review of current assessment methods. Journal of teaching and learning for graduate employability, 1(1), 13-25.

[20] Malaney, G. D. (1985). An organizational perspective of graduate student recruitment: A resource dependence approach. The Review of Higher Education, 8(4), 375386.

[21] Clark, I., \& Clark, T. (1990). Personnel Management and The Use of Executive Recruitment Consultancies1. Human Resource Management Journal, 1(1), 46-62.

[22] Clark, T. (1992). Management selection by executive recruitment consultancies: A survey and explanation of selection methods. Journal of Managerial Psychology, 7(6), 3-10.

[23] Clark, T. (1993). Selection methods used by executive search consultancies in four European countries: A survey and critique. International Journal of Selection and Assessment, 1(1), 41-49.

[24] Christine Britton, L., \& Ball, D. F. (1994). Executive search and selection consultancies in France. European business review, 94(1), 24-29.

[25] Bartram D. (2000). Internet recruitment and selection: Kissing frogs to find princes. International Journal of Selection and Assessment, 8(4), 261-274

[16] Taylor, M. S., \& Sniezek, J. A. (1984). The 
[26] Piturro, M., (2000). "The Power of ECruiting”, Management Review, 89(1), 3337.

[27] Anderson N. (2003). Applicant and recruiter reactions to new technology in selection: A critical review and agenda for future research. International Journal of Selection and Assessment, 11(2/3), 121-136.

[28] Bauer, T. N., Truxillo, D. M., Paronto, M. E., Weekley, J. A. and Campion, M. A. (2004), Applicant Reactions to Different Selection Technology: Face-to-Face, Interactive Voice Response, and ComputerAssisted Telephone Screening Interviews. International Journal of Selection and Assessment, 12(1), 135-148.

[29] Ruël, H., Bondarouk, T., \& Looise, J. K. (2004). E-HRM: Innovation or irritation. An explorative empirical study in five large companies on web-based HRM. Management revue, 364-380.

[30] Puck, J. F., Mohr, A. T., \& Holtbrügge, D. (2006). Cultural convergence through webbased management techniques? The case of corporate web site recruiting. Journal of International Management, 12(2), 181-195.

[31] Maurer, S. D., \& Liu, Y. (2007). Developing effective e-recruiting websites: Insights for managers from marketers. Business horizons, 50(4), 305-314.

[32] Allen, D. G., Mahto, R. V., \& Otondo, R. F. (2007). Web-based recruitment: effects of information, organizational brand, and attitudes toward a Web site on applicant attraction. Journal of Applied Psychology, 92(6), 1696.

[33] Rozelle, A. L., \& Landis, R. S. (2002). An examination of the relationship between use of the Internet as a recruitment source and student attitudes. Computers in Human Behavior, 18(5), 593-604.

[34] Parry, E., \& Wilson, H. (2009). Factors influencing the adoption of online recruitment. Personnel Review, 38(6), 655673.
[35] Dineen, B. R., Ash, S. R., \& Noe, R. A. (2002). A Web of applicant attraction: person-organization fit in the context of Web-based recruitment. Journal of Applied Psychology, 87(4), 723.

[36] Backhaus, K. B. (2004). An exploration of corporate recruitment descriptions on Monster. com. The Journal of Business Communication (1973), 41(2), 115-136.

[37] Hamilton, R. J., \& Bowers, B. J. (2006). Internet recruitment and e-mail interviews in qualitative studies. Qualitative Health Research, 16(6), 821-835.

[38] Färber, F., Weitzel, T., \& Keim, T. (2003). An automated recommendation approach to selection in personnel recruitment. AMCIS 2003 proceedings, 302

[39] Lori Foster Thompson, Phillip W. Braddy, Karl L Wuensch., (2008). E-recruitment and the benefits of organizational web appeal. Computers in Human Behaviour, 24(5), 2384-2398.

[40] Hella, Sylva., Stefan T. Mol. (2009). ERecruitment: A study into applicant perceptions of an online application system. International Journal of Selection and Assessment, 17(3), 311-323.

[41] Girard, Aurelie., Fallery, Bernard., (2009). E-recruitment: new practices, new issues, An exploratory study. Human Resource Information System, INSTICC Press, 3948.

[42] Bondarouk, T. V., \& Ruel, H. J. M. (2009). Electronic Human Resource Management: challenges in the digital era. The International Journal of Human Resource Management, 20(3), 505-514.

[43] Doherty, R. (2010). "Getting social with recruitment”, Strategic HR Review, 9(1), 11-15

[44] Holm., Anna B., (2012). E-recruitment: Towards an Ubiquitous Recruitment Process and Candidate Relationship Management, German Journal of Research 
in Human Resource Management, 26(3), 241-259.

[45] Thielsch, M. T., Träumer, L. \& Pytlik, L. (2012). E-Recruiting and fairness - the applicant's point of view. Information Technology and Management, 13 (2), 5967.

[46] Rathod, N., Shah, S., \& Shirsat, K. (2013). An Interactive Online Training \& Placement System. International Journal of Advanced Research in Computer and Communication Engineering, 3(12).

[47] Hadkar, Shilpa., Baing Snehal., Harer Trupti., Wankhede Sonam., Reddy, K.T.V. (2014). College Collaboration Portal with Training and placement. IOSR Journal of Computer Engineering (IOSR-JCE), 16(2).

[48] Kasture, Hitesh., Saraiyya, Sumit., Malviya, Abhishek., Bhagat, Preeti. (2014). Training \& Placement Web Portal. International Journal on Recent and Innovation Trends in Computing and Communication, 2(3).

[49] Bhad, Nilesh., Kumble Pooja., Saini, Sunita., Thorat, Yogesh., (2016). Review on an Interactive Training and Placement System. International Journal of Advance Engineering and Research Development, 3(11). pp. 251-254.

[50] Kulkarni, Anagha., Hajare, Priyanka., Khandave, Priyanka., Adhav Shital., Pimpale, Swati. (2016). Implementation of Online Placement System. International Journal of Emerging Research in Management \&Technology (IJERMT), 5(1)

[51] Katwa, Charlotte., Kashmira Sanjana., Parmar, Pooja. (2016). Final year placement management system, International Journal of Scientific and Technical Advancements, 2(1), 233-234.

[52] Brandão, C., Morais, C., Dias, S., Silva, A. R., \& Mário, R. (2017). Using Online Recruitment: Implicit Theories and Candidates' Profile. World Conference on Information Systems and Technologies Springer International Publishing, 293-301.
[53] Shenoy, Varun., \& Aithal, P S. (2017). A New Box Framework for E-Campus Interview Training. International Journal of Applied Engineering and Management Letters (IJAEML), 1(2), 17-26.

[54] Shenoy, Varun., \& Aithal, P S. (2016). ABCD Analysis of On-line Campus Placement Model. IRA-International Journal of Management \& Social Sciences, 5(2), 227-244.

[55] Shenoy, Varun., \& Aithal, P S. (2016) . Changing Approaches in Campus Placements : A New Futuristic Model. International Journal of Scientific Research and Modern Education (IJSRME), 1(1), 766-776.

[56] Shenoy, V., \& Aithal, P. (2016). Green Placement - An Innovative Concept \& Strategy in Campus Placement Model. IRA-International Journal of Technology \& Engineering, 4(3), 151-163.

[57] Wiley, C. (1992). Recruitment research revisited : Effective recruiting methods according to employment outcomes. Journal of Applied Business Research, 8(2), 74.

[58] Van Latham, M., \& Leddy, P. M. (1987). Source of recruitment and employee attitudes: An analysis of job involvement, organizational commitment, and job satisfaction. Journal of Business and Psychology, 1(3), 230-235.

[59] Zottoli, M. A., \& Wanous, J. P. (2001). Recruitment source research: Current status and future directions. Human Resource Management Review, 10(4), 353-382.

[60] Marsden, P. V. (1994). The hiring process: recruitment methods. American Behavioral Scientist, 37(7), 979-991.

[61] Sills, M. (2014). E-recruitment: A comparison with traditional recruitment and the influences of social media. Helsinki Metropolia University of Applied Sciences, European Management, 1-50. 